\title{
Por uma história política do cultural
}

Entrevista

\author{
Fernando Bouza*
}

A história, tal como a escreve Fernando Bouza, vai de par com seu gosto profundo pelo arquivo e pelo livro. É ele que guia o caráter de sua vasta obra, que não se pretende inovadora, mas que inova, de saída, pela inclusão imediata de sua própria experiência — não apenas crítica, mas também sensorial - de historiador entre livros e papéis. É assim que a materialidade dos textos e sua lógica de classificação e de conservação, antiga e moderna, passam a constituir o rol de instrumentos de reflexão desse historiador das sociedades ibéricas do Antigo Regime. As formas orais, visuais e escritas (manuscritas e impressas) de emissão e de recepção cultural, com seus efeitos políticos plurais, surgem em seus livros numa diversidade de estudos de casos que náo apenas informam as descontinuidades das modalidades de comunicação, de conhecimento e de memória. Elas servem também para redefinir as perguntas a serem lançadas sobre as múltiplas formas políticas do Estado moderno, desconstruindo assim a teleologia historiográfica do exercício central do poder monárquico.

Há pouco mais de dez anos, exatamente em 2003, Bouza concedeu uma entrevista à revista Topoi. ${ }^{1}$ Aqui, esse diálogo se renova em torno de quatro grandes blocos temáticos. O primeiro bloco é dedicado à sua obra, na sua relaçáo com a historiografia, nesta última década. O segundo, sobre o trabalho do historiador, trabalho de arquivo, de que ele é grande especialista. $\mathrm{O}$ terceiro é dedicado à sua visão da historiografia contemporânea. E o quarto é voltado para as potencialidades de uma agenda de estudos que poderíamos chamar, de maneira genérica, de o "período filipino", em que se inserem muitos de seus trabalhos, recobrindo, evidentemente, Espanha e Portugal, mas também o Brasil.

Andrea Daher: Lembro que, na entrevista concedida em 2003, você nos falava da abordagem - muito original, naquele momento - dos usos orais e visuais de determinados objetos, pela cultura aristocrática de corte nos séculos XVI e XVII. Era o momento da publicação do seu livro Palavra e imagem na corte: cultura oral e visual da nobreza no Século de Ouro (Madri: Abada Editores, 2003). Com este livro, pode-se dizer que comunicar e forjar

\footnotetext{
* Entrevista realizada em 19 de junho de 2013, no Programa de Pós-graduação em História Social da UFRJ. Apresentação, edição e revisão final de Andrea Daher.

DOI - http://dx.doi.org/10.1590/2237-101X016030012

${ }^{1}$ BOUZA, Fernando. Entrevista. Topoi. Revista de História, Rio de Janeiro, v. 4, n. 7, p. 357-361, jul./dez. 2003. Disponível em: <http://www.revistatopoi.org/numeros_anteriores/Topoi\%2007/topoi7ent.pdf>.
} 
memória, à época, eram elementos eficazes nas lutas de representação do que você chama "ethos estamental", ou seja, a produção de distinção e de legitimação pela aristocracia cortesã - o que você estabelecia em sintonia com as proposições de Norbert Elias. Passados dez anos, a pergunta agora seria a seguinte: o que mudou, do ponto de vista da historiografia, de um modo geral, em relação precisamente à oralidade, à produção de memória, nessa chave de análise das lutas de representação de um "ethos estamental" como o da aristocracia de corte do Século de Ouro e, em suma, em relação às conclusões mais importantes veiculadas no seu livro, em 2003?

Fernando Bouza: Em primeiro lugar, quero agradecer o convite, a presença de todos e especialmente a atenção e a confiança que depositaram em mim, ao imaginar que me ouvir pode ter algum resultado positivo.

Com relação à pergunta, a mudança foi importante. Importante no meu próprio trabalho, mas, também, na historiografia de que meu trabalho, obviamente, é só um eco. Resumindo, acho que se produziu uma recuperaçáo, pelo menos em parte, de horizonte. Explico brevemente. Quando, há dez anos, eu trabalhava sobre a palavra e a imagem na cultura aristocrática, tentava voltar minha atenção para fenômenos que não tinham sido estudados até esse momento. Era, especialmente, uma tentativa de recuperar "vozes". Ainda me movia a ideia de reconstruir as categorias da época, "seu" léxico, "suas" formas de expressão, "sua" luta política. Esperava poder encontrar no oral e no visual expedientes de luta política e de diferenciação. Dez anos depois, acho que tentei — e tento ainda — não apenas reconstruir as categorias da época. Cada vez mais, estou a procura de um horizonte maior. É como se a historiografia internacional voltasse a desejar ter um horizonte. $\mathrm{O}$ que quero dizer com "horizonte"? Isso não supóe, de modo algum, voltar à ideia clássica de progresso, recuperar a ideia de que "é preciso saber como se lia em 1450 para explicar que hoje lemos de uma maneira e não de outra”. Creio que os tempos e os espaços foram ampliados. De alguma maneira, recuperei objetivos que me fazem medir a história com séculos mais longos, me afastando talvez um pouco mais do contexto concreto da aristocracia ibérica. Esse horizonte, para mim, e, pelo que entendo, para muitos outros historiadores, é o surgimento da esfera pública. Quer dizer, trata-se de uma história da comunicação que passou, creio eu, a ser uma história da comunicação política. Eu sempre quis fazer história cultural da política, uma história cultural social. E, no fundo, me atreveria a dizer que faço mais história social do que história cultural. Mesmo que estes sejam termos de bandeiras ou etiquetas, por assim dizer. Eu sempre me considerei um historiador generalista, um historiador do mundo ibérico dos séculos XVI e XVII.

Voltando ao argumento sobre o que mudou nos últimos dez anos: passei de uma história da comunicação e da memória a um objetivo maior, o da construção da esfera pública. Quer dizer, agora, quando falo de voz, de imagens, de imprensa e de cópia manuscrita, eu o faço 
tentando reconstruir um processo maior, um laboratório em que surgiu uma esfera pública, relacionado com os meios de comunicação. Assim, mudei, ampliei a escala; continuo fazendo estudos de casos, pensando por casos — poderíamos dizer assim, penser par cas —, mas agora com uma escala maior no tempo e no espaço, e com um horizonte. Não digo meta, não digo destino; digo horizonte, o que seria a construção da esfera pública e o surgimento da opinião pública. Isso mudou, e para mim foi uma mudança natural e importante.

Andrea Daher: E como se deu essa construção, então, em torno da esfera pública?

Fernando Bouza: Como vocês sabem, a história da imprensa é uma história de revolução: a célebre "revolução da imprensa". Eu vou contar desta maneira. Em primeiro lugar, se supunha que a imprensa era uma revolução do moderno diante do medieval. Hoje, esta é uma ideia completamente superada. A segunda ideia de revolução da imprensa é a de que ela surge como um novo sistema que gera o racionalismo, segundo o modelo de McLuhan, que também foi, em parte, superado. A terceira ideia, que acho a mais interessante, é a de que a imprensa náo foi revolucionária nem pelas suas produçóes nem porque gerou uma forma única de leitura, já que existiam formas de leitura em voz alta etc. Mas ela foi "revolucionária" — e revolucionária entre aspas — , sim, porque gerou novas relaçóes e novas realidades para a época. A primeira delas seria o público moderno, que é uma realidade muito pouco estamental. A segunda tem a ver com as possibilidades mercantis próprias da imprensa. Elas fizeram com que o mundo do que foi chamado "cultura popular", ou pequena tradição, se preferirem, se transformasse em texto impresso e pudesse ser consumido por pessoas de tradição letrada. Mas, ao mesmo tempo, a grande tradição pode ser difundida no mundo da pequena tradição por meio da imprensa em línguas vernáculas, através da edição dos clássicos romantizados, de formas de leitura em voz alta etc. Quer dizer que aqui a imprensa se apresenta como revolucionária não por ser promotora de um novo corpo de textos, mas pelas novas relaçóes sociais e políticas que pode gerar. De um lado, sabemos bem, está a propaganda que vem de cima para baixo e que recorreu amplamente às imprensas tipográficas; de outro lado, de baixo para cima, há o fato de que as populaçóes puderam dar respostas às medidas tomadas pelos governantes sobre a base de textos que também puderam chegar à imprensa. Portanto, a imprensa me interessa como uma forma de fazer chegar, de colocar em circulação conhecimentos, notícias, afetos, o que quisermos. E também como um elemento de construção de novas comunidades. O público moderno é, para mim, uma comunidade totalmente nova, entendido como público massivo e indiscriminado. E isso, claro, me faz lembrar que Gabriel Naudé - que todos vocês conhecem, autor do clássico do pensamento absolutista, Considérations politiques sur les coups d'état (1639) — era bibliotecário. Esse público moderno, como digo, é um público não estamental: porque há pessoas de distintas condições, letradas e iletradas, que fazem leitura em voz alta, e pessoas com representação 
política diferenciada (nobres, eclesiásticos, povo) que, entretanto, estão unidas porque leem os mesmos textos e porque gostam dos mesmos textos. Em Dom Quixote (I, 32), vocês lembram, todos gostam dos livros de cavalaria: o fidalgo, o sacerdote, Sancho, o taberneiro, a mulher do taberneiro, Maritornes etc. Pessoas que sabem ler e outras que não sabem. Pessoas que, no fundo, do ponto de vista da representação estamental pertenceriam a mundos diferentes, mas que, entretanto, estáo unidos porque todos eles leem ou ouvem ler livros de cavalaria, que são os de que mais gostam. Essa nova comunidade criada pela imprensa parece ter tido também uma atração muito forte para os reis que, não em vão, ao longo da Idade Moderna, da Alta Idade Moderna, se transformaram em autores. Elizabeth da Inglaterra é tradutora e autora; Jaime VI, Stuart, é autor publicado; Felipe IV de Habsburgo é tradutor; Luís XVI é tradutor publicado; Felipe V de Bourbon é tradutor publicado. Do ponto de vista da história do poder, pensem nas possibilidades de imaginar uma nova forma de representar a comunidade política, na qual o reino é o público - massivo, indiscriminado, da imprensa - e o monarca absoluto, este sim absoluto, é um autor. Para mim, isso supóe grandes possibilidades. E, na prática, acho que para o mundo ibérico isso foi importante. É claro, devo fazer operações que, em princípio, são operações de reconstrução do vocabulário político e do léxico da época, a que nunca vou renunciar, e vou continuar pensando por casos. Mas, agora, talvez, com um horizonte temporal maior, de 1521 a 1711, por exemplo.

E, também, mudei a escala. Por exemplo, como lhes dizia, tenho de voltar a pensar a propaganda. Até agora, aceitamos que a propaganda era coisa própria dos reis. Mas, agora, nos deparamos com o fato de que se publicam textos em defesa e de legitimação de uma conduta particular, comunitária, coletiva, através da imprensa ou do manuscrito. Isso foi algo feito por todos os tipos de pessoas, de indivíduos a corporaçóes, a cidades, grêmios, transformadas em pessoas ou grupos que desejam tornar públicas as suas razóes para agir de uma forma ou de outra. Por exemplo, Francisco Manuel de Melo: esse grande escritor português foi detido em Madri ao voltar da Guerra da Catalunha, suspeito de ser um agente dos Bragança, depois do Primeiro de Dezembro de 1640. Uma cédula real de Felipe IV, de março de 1641, o isenta de qualquer dúvida sobre a sua lealdade. D. Francisco Manuel faz com que esse texto seja publicado, o leva à imprensa, de forma a transformá-lo num texto que possa ser apresentado como testemunho de sua lealdade. É verdade que teve de imprimir poucos exemplares, pois a cédula de 1641 é uma peça muito rara no corpus de Francisco Manuel de Melo, possivelmente a mais rara que existe. Eu, pelo menos, só consegui ver um exemplar na minha vida. Esse impresso é também, sem dúvida, propaganda, mas propaganda de um só. E, além disso, a propaganda, a vontade de difundir, de justificar e de tornar pública uma postura determinada pode ser propaganda desde baixo, não só de cima, como a clássica propaganda monárquica.

Sabe-se, ainda, que houve pessoas analfabetas que buscaram um memorialista para que escrevesse por eles um "papel”, e que, mais tarde, o fizeram ser publicado. Porque, no final 
das contas, a imprensa tem uma dimensão fortemente mercantil. Onde houvesse uma instalada, todos poderiam recorrer a ela e, por mais que nos custe acreditar, era relativamente fácil se transformar em autor no século XVII. De forma que, insisto, trabalhando sobre casos de particulares que recorrem à imprensa dizendo "meu parecer sobre a Guerra de Portugal é este ou aquele", me vejo frente ao fato de que, efetivamente, eles participam no debate comunitário através da imprensa, e que esta gerou novos autores, como disse.

Alguns desses novos autores foram pessoas comuns; pessoas que, possivelmente, não teriam tido a chance de participar de um debate até essa eclosão seiscentista da imprensa. E a situação se torna, inclusive, ameaçadora, de forma que se criou em 1648, na Espanha, uma nova instância jurisdicional, sobre a qual não sabíamos quase nada até dois anos atrás: o "Juiz Superintendente de impressôes e de livros relativos ao Governo Geral e político e causa pública”. Foi criada em 1648 por Felipe IV, precisamente, para que existisse um juiz único e privativo que aprovasse, que censurasse as obras, em ocasiôes apenas de papéis de poucos ofícios, que tratassem de assuntos de governo geral e de causa pública. Isso porque cada vez mais havia particulares que usavam a imprensa para tornar públicas suas ideias e observaçóes. E, dessa maneira, pude passar de uma história das formas de comunicaçáo para uma história da esfera pública. No fundo, o que me interessa não é exatamente quais foram os argumentos das polêmicas, mas quais foram os meios mediante os quais as pessoas comuns ou os particulares puderam fazer com que se ouvissem seus pareceres sobre questóes que antes eram gerais. Talvez não pudessem fazê-lo através das instituiçóes representativas, como as cortes ou assembleias, nem mesmo através das facçôes da corte régia. Mas, para a minha surpresa, e possivelmente também para a surpresa deles naquele tempo, o puderam fazer graças à imprensa — que era, como já disse, um meio muito mercantilizado. Para os textos que não afetassem a religião ou o sistema político, a única coisa que era preciso fazer era ter uma autorização de censura prévia e reunir dinheiro para imprimir. Assim, se pode dizer que era muito mais fácil se transformar em autor de um texto impresso em 1630 do que em 1750.

Lise Sedrez: Nessas discussóes sobre as modificaçôes da imprensa e o papel que ela tem, em várias esferas, na criaçáo do poder público, peço que você fale um pouco sobre o que representou, na regiáo ibérica, essa mudança material. Estou me recordando de alguns trabalhos feitos sobre a produção de livros em Veneza, como o de Mario Infelise, L'editoria veneziana nel'700 (Milão: Franco Angeli, 2000). O que significou a produção do papel e a presença de imprensa em pequenas e grandes cidades? Essa difusão do ofício do tipógrafo, da criação da imprensa, como você disse, a ponto de qualquer pessoa, dentro de certos limites, poder publicar alguma coisa: o que isso significou nessa modificação da sociedade ibérica?

Fernando Bouza: No mundo ibérico, efetivamente, encontramos, no período barroco, um certo caos de imagens, de rumores, de textos. Um caos que me lembra alguns momentos 
do século XIX, como o período entre 1808 e 1814, na Espanha e em Portugal, quando se produz uma eclosão semelhante de textos, de imagens e de vozes. Porque, é claro, mesmo que eu tenha falado aqui de imprensa, quero lembrar que de nenhuma maneira se pode imaginar o passado sem manuscritos, sem imagens e sem vozes. Sem esquecer tudo isso, na minha opinião, a imprensa é possivelmente o mais operativo desses sistemas, precisamente porque é um sistema muito mercantilizado. Quer dizer, é um sistema no qual a relação com os impressores é mercantil: alguém tem um texto e busca imprimi-lo. Se for um texto que não vai ser vendido, ou seja, se não for produzido um lucro econômico com a venda desse texto, na Espanha dos séculos XVI e XVII não era necessário pedir licença real aos Conselhos para imprimi-lo. Por exemplo, se alguém fizesse um memorial sobre a Guerra de Portugal e não o quisesse vender, este texto poderia ser impresso legalmente, sem autorização oficial, até 1648. É importante que isso seja lembrado.

Ademais, é o particular que vai à imprensa com seu manuscrito e paga para que ele seja impresso. É, por assim dizer, como fazemos hoje os nossos cartôes de visita. Imaginem que vocês vão a uma gráfica e encomendam cem cartôes de visita - pessoalmente, meus pais encomendaram cartôes de visita para mim quando me tornei doutor, imagino que algo assim tenha acontecido com todos nós. Bem, como disse, alguém chegava com um parecer sobre a Guerra de Portugal junto a um impressor e fazia imprimir cem pareceres, que eram postos em circulação direta, pois não havia um sistema editorial como o atual, nem nada do estilo. E, durante boa parte dos séculos XVI e XVII, as normas ainda eram frouxas para este tipo de impressão que não se vendia.

Por último, observo que a imprensa chega também a todo lugar onde se instalou a maquinaria para imprimir. A própria reprodutibilidade da mecânica impressa é relativamente simples. Por exemplo, o irlandês Albert O'Farail, ou O’Ferral, chegou a Madri na década de 1670 com a pretensão de imprimir livros para a missão da Irlanda. Ele dizia que os livros impressos eram missóes mudas, porque nos lugares onde os missionários não podiam chegar, chegavam os livros. E este Mr. O’Farail não encontrou ninguém em Madri que soubesse compor os caracteres de imprensa em inglês; talvez ele também não os encontrasse, se procurasse hoje. E o que ele fez? Aprendeu ele mesmo, se transformou em impressor, se tornou autor do texto e seu compositor. Algumas pessoas tiveram imprensas particulares em suas casas. Por exemplo, em meados do XVII, Gaspar de Haro, marquês do Carpio, teve uma imprensa completa em sua casa que, é claro, não era ele que movia. Mas, nela, o marquês editava pequenos folhetos das comédias do Coliseu de Madri, cujos exemplares presenteava de forma exclusiva. Ramiro Nuñez de Guzmán, duque de Medina de las Torres, também teve uma imprensa para seus pleitos. Em suma, onde há imprensa, pode haver livros impressos. Se pensarmos bem, é particularmente nas reduçôes jesuíticas do XVIII que, se há imprensa e alguém que sabe usá-la, há impressos. Neste sentido, é certo que a imprensa gera novos autores porque mercantiliza a escrita e a autoria. E, em segundo lugar, porque 
onde existir alguém que saiba imprimir (e como acabamos de dizer, não era táo complicado aprender a fazer isso), poderá existir um impressor. A reação foi complicada e dupla: de um lado, encontramos testemunhos dos outros impressores, aqueles que faziam livros para autores mais "honrados", que reclamam desses pequenos textos, dizendo que são apenas receitas ou miudezas, que não valem nada, e que são eles que fazem os grandes livros. De outro lado, esses novos autores publicados que têm acesso à imprensa são muito criticados pelos autores considerados profissionais. Quer dizer, a República das Letras hispânica reclamava muito dessa profusão de letras. Por exemplo, este é o caso do autor chamado Luiz López, que era um confeiteiro, que fazia massa folhada, e tinha aberto algumas lojas em Saragoça, o que o tornou bastante rico. $\mathrm{O}$ confeiteiro tinha comprado os manuscritos de um erudito genealogista. Assim, com esses antigos manuscritos e sua própria curiosidade, decidiu se converter em autor impresso. E, de fato, ele publicou vários livros sob seu próprio nome - neste caso, livros completos, não folhetos —, que imprimiu por sua conta, pagando diretamente os gastos da emissão. Os cronistas e os autores autorizados - me permitam a expressão - se indignaram. Um deles o chamou depreciativamente de "o folheador"; outro afirmou: "tristes tempos, quando qualquer um se atreve a escrever e estampar". O próprio López responde, em 1638, que, por mais que náo escrevesse com "pena de ganso", tinha o direito de "fazer a ponta com tantas outras, como as das águias que voam nas alturas". ${ }^{2} \mathrm{O}$ que mais me interessa aqui é essa ideia de que a imprensa gera e propicia o aparecimento de novos autores.

LISE SEDREZ: Esses comentários parecem espelhar a reação de certos jornalistas à criação de blogs, nos dias de hoje, na internet.

Fernando Bouza: Isso me interessa muito. Vejam, o mundo da internet é um mundo que lembra muito essa espécie de caos que estou tentando apresentar a vocês. A internet gerou, primeiro, a estupefaçáo dos autores tradicionais. Pouco a pouco, eles foram se incorporando à rede. Mas, se observarmos bem, o que a internet faz é gerar novos autores. Novos autores que recuperaram formas antigas de autoria. Quer dizer, há novos autores que, tomando uma parte aqui e outra acolá, se tornam compiladores. Há novos autores que são glosadores, que comentam os textos de outros e os guardam. Há novos autores que são pessoas que unicamente colocam textos na rede. Então, esse impacto das novas tecnologias, concretamente o da internet sobre a autoria, me parece bastante interessante. Não é que aconteça o mesmo com a imprensa, é claro que não. Mas trata-se, sim, de uma difusão que gera novas escritas, novas práticas.

A reação dos Felipes, no século XVI, foi um pouco singular. Primeiro, houve reclamaçôes: o marquês de los Vélez, em 1599, lavra uma frase na pedra: "Já não existe quem não imprima." No final do século XVI, todo mundo já imprime. Foi então que houve, como

\footnotetext{
2 "hacer punta con tantas otras como vuelan de remontadas águilas".
} 
disse, a criação em 1648 do cargo de juiz superintendente em matérias de imprensa, uma figura especial para que todos os textos impressos tivessem um juiz único. $O$ poder não sabe, portanto, como reagir diante do surgimento de tantos autores, e tenta controlá-los, precisamente com medidas como a criação dessa nova magistratura para textos que, até esse momento, como dissemos antes, estavam circulando sem censura.

Imagino que isso também nos permita compreender ou refletir sobre o que acontece na atualidade. Sou muito pouco chegado a fazer comentários sobre a atualidade por temor de cair em preconceitos. Entretanto, proponho que vocês estabeleçam a relação por si sós: quem quiser ver uma relação entre a imprensa popularizada, digamos, do barroco ibérico, e a situação da internet hoje, que o faça. Mas não fui eu quem fez, apenas deixei a evocação em sua memória (porque, claro, jogo com a memória de vocês)!

Voltando à ideia do caos que imperava nos anos 1600, 1610, 1620, havia um grande número de autores na Inglaterra, na França, na Espanha e em Portugal que se perguntavam, inclusive com humor, o que estava acontecendo naqueles tempos em que viviam, quando tudo estava mudando. Um autor inglês como Gabriel Harvey se perguntava por que as pessoas não estavam lendo o que deveriam ler. O letrado lê livros de cortesãos, lê Castiglione, e não Duns Scott. É um mundo às avessas. Em Portugal, no texto satírico que eu mencionava antes, se pergunta: "O que está acontecendo? Por que não comemos o que é nosso e, sim, o que é dos outros?". O texto lusitano Senatus consultus, de Celorico, ${ }^{3}$ diz que os brasileiros comem seus abacaxis, enquanto os portugueses comem goiabadas e açúcar de mel. Este é um testemunho de uma precoce globalização alimentícia. Existem vários testemunhos do começo do século XVII que falam de um mundo que está se mesclando. Com efeito, a imprensa é um instrumento dessa mescla, e isso a torna especialmente interessante. Mas, é claro, ela também apresenta seus problemas. Por exemplo, como vocês já sabem, ela fixa os textos, reproduzidos em centenas de exemplares a partir de um único original.

Eugenio Asensio, esse grande autor espanhol que todos os historiadores modernistas espanhóis gostariam de ter como mestre — todos, de alguma maneira, procuramos estabelecer uma relação para poder dizer que somos discípulos de Asensio - , percebeu que a imprensa tinha permitido que os romances populares chegassem até nós em versão impressa. Mas Asensio se perguntava se isso não teria custado ao romance o freio de sua evolução. Porque a imprensa, de alguma maneira, ao fixar o texto, o seca, o transforma em algo fóssil. Assim, é claro, ele pode ser copiado, imitado, reproduzido, mas tende a perder uma parte de sua capacidade de nova criação.

Voltando ao tema da atualidade, percebam que o que a internet não conseguiu superar foi o códice. As primeiras imagens de textos na internet editados na rede nos fizeram recu-

\footnotetext{
${ }^{3}$ Senatus consultus, texto enviado pela vereação de Celorico, em 1624, ao Conselho de Portugal, em Madri. Cf. MARTINS, Carla. Bibliografia crítica sobre a temática de Celorico da Beira. Dissertação (Mestrado em Ciências Documentais) — Universidade da Beira Interior, Covilhã, 2011.
} 
perar o mundo do rolo. Temos o rolo na tela, como se voltássemos à imagem da leitura em rolo, um rolo que vai passando. Mas os editores perceberam que isso tinha inconvenientes. Por exemplo, nos primeiros anos da internet, as pessoas náo podiam parar de ler um texto num dia e voltar a ler no dia seguinte, no mesmo ponto. Isso, que antes não era possível fazer, agora é. Por isso, ler hoje na internet significou recuperar uma série de práticas próprias da leitura do códice como desenho. Já podemos, assim, marcar o lugar em que deixamos a leitura na tela. A tela pode aparecer dividida em duas folhas; alguns servidores, inclusive, nos permitem ouvir um ruído de página quando se muda a folha/tela. Quer dizer, a internet mudou, sim, o estatuto do autor e do público, mas ela não conseguiu ir no sentido contrário dessa forma maravilhosa que é o códice. Trata-se de um desenho, dos melhores desenhos que existem, e que está há quase dois milênios entre nós.

Um autor de sermóes do começo do século XVII, por exemplo, se pergunta se é melhor ouvir ou ler um sermão. Evidentemente, é melhor ouvir um sermão, por conta do aspecto retórico - a expressividade do sermão que se ouve quando o padre, com sua voz educada, pode ir do sussurro ao grito, é muito difícil de transportar às figuras da retórica em papel. Mas esse mesmo autor diz que, por mais que o sermáo ouvido diretamente seja melhor, o sermão escrito é também muito proveitoso porque nos permite deixar de ler hoje, dormir e voltar a ler amanhã, exatamente na mesma passagem em que se havia parado. E, sem dúvida, os sermóes que duravam muito tempo — os sermóes de verão não podiam durar mais de duas horas; os sermóes de inverno podiam durar até mais de três horas - eram um exercício, uma representação que não podemos imaginar hoje em dia.

Com o livro, posso chegar exatamente numa passagem e lê-la no dia seguinte. O códice, como vocês bem sabem, permite ainda comparar duas passagens textuais. Por exemplo, uma do Antigo Testamento e outra do Novo, ou uma passagem do Êxodo e outra do Evangelho de São João. Esta operação é muito difícil de ser feita a partir de um rolo, de um pergaminho em rolo, mas muito simples a partir de um códice/livro. Era o que acontecia com as telas antes de a internet dar o salto e imitar o códice. Talvez a internet pudesse acabar com o códice, mas, na prática, acabou por imitá-lo. O desenho do códice, por enquanto, é bastante durável.

Andrea Daher: O segundo problema é a prática do comentário, da glosa, que tem de se transformar na relação com suportes como o rolo e, hoje, a tela.

Fernando Bouza: Sim, é claro. O mundo medieval teve quatro grandes figuras de autoria: o escritor, o compilador, o glosador e o autor. $\mathrm{O}$ primeiro é aquele que copia o texto materialmente. $\mathrm{O}$ segundo reúne partes do texto para fazer um novo, tomando, por exemplo, capítulos de Aristóteles, Sêneca ou Cícero (imaginem esta operação hoje, com a internet, é fácil fazer). $\mathrm{O}$ terceiro parte de um texto e faz glosas que podem ser incorporadas 
no texto principal ou ao lado dele, na forma clássica de mandorla. ${ }^{4} \mathrm{O}$ quarto seria o autor, que escreve um texto novo, tendo por base suas leituras e citações de obras anteriores. É nesta figura de autoria que prima a imprensa. Agora, recuperamos formas de autoria que, de alguma forma, tinham se perdido durante o período da imprensa manual e mecânica.

Andrea Daher: O universo de circulaçóes, de usos, de emergência de novas práticas através desses usos, pode ser caracterizado por uma figura conceitual, digamos, que é a figura da tensão. Na verdade, quando você diz que um texto fixa, ao mesmo tempo há fixação e há mescla. A eficácia dessa categoria "mescla” talvez seja maior para o século XVI do que a de globalização, sobretudo nesse mundo em que o oral, o escrito e o icônico convivem em interface. É nesse sentido que há sempre tensão, e nunca totalmente fixação. Em todo caso, há formas de uso mais plásticas, como as que você descreve num livro, publicado em francês, que se intitula Hétérographies: formes de l'écrit au Siècle d'Or espagnol (Madri: Casa de Velázquez, 2010). A ideia de tensão define muito bem uma heterografia. Na sua última resposta, você nomeou três formas de heterografia que correspondem à seguinte tipologia: uma primeira heterografia seria a da palavra escrita como produtora de presença de alguma coisa ausente. Uma segunda heterografia seria a persistência da manuscritura, cuja análise encontramos, ainda, em outro livro seu, Corre manuscrito: una historia cultural del Siglo de Oro (Madri: Marcial Pons, 2001). E, em terceiro lugar, a tradução. Creio que essas três heterografias são campos férteis para se pensar a tensão entre fixação e plasticidade de determinadas práticas culturais.

Fernando Bouza: A heterografia é outra forma de ver a cultura escrita, outra grafia. Em primeiro lugar, o mais interessante é que se trata de uma noção que, de alguma forma, implica reconhecer que cada um de nós, cada um dos ouvintes, cada um dos escritores, dos historiadores, no final das contas se depara como autor diante de um público. É uma história que se repete uma vez ou outra, quando temos então de lidar com a memória dos outros. Memória no sentido das expectativas dos outros, o que eles já sabem, as tópicas, os lugares comuns. De forma que escrever heterografias supóe partir do fato que há uma "orto-grafia" em que se resume a história cultural da escrita para o mundo ibérico dos séculos XVI e XVII. Ou seja, a heterografia carrega implícito o reconhecimento de que primeiro existiu uma ortografia, quer dizer, uma forma correta de escrever sobre a cultura escrita do período moderno. E nessa cultura "ortografada" (que assinala o que teria sido o correto), em vez de formas eficazes, nas quais a escrita produz efeitos sensíveis por si mesma, encontrávamos usos racionais que falavam do texto como um depósito racional, um lugar que deve ser desentranhado através da razão. Isso fazia com que fossem ocultados outros usos que os textos escritos também tinham no Século de Ouro, quando podiam ser tocados, apalpados, senti-

\footnotetext{
${ }^{4}$ Auréola de forma amendoada que, na arte religiosa, circunda uma figura sacra. 
dos sobre a pele ou, até mesmo, ingeridos, comidos. Em segundo lugar, a ortografia passou a dizer respeito à imprensa, e náo ao manuscrito. Em terceiro lugar, os textos se centravam nos autores (Cervantes, Camóes, Faria e Sousa), e não nos tradutores. Ou seja, para mim, a primeira ideia de heterografia relaciona-se com a ideia de se fazer outra história da cultura escrita, oral e visual dessa época. E também há algo de heterográfico no fato de insistir que esta história pode ser escrita também no arquivo - coisa que, para mim, é especialmente importante —, ou que essa outra história é tão ou mais rica do que a história tradicional.

No fundo, o que é proposto é algo que todos sabemos e, mesmo assim, esquecemos com frequência: o passado é um lugar distinto. Eu gosto muito da ideia de alteridade do passado. Quando visitamos a Biblioteca de San Lorenzo do Escorial de Felipe II - cuja imagem certamente vocês têm em seu imaginário por fotografias —, percebemos que os livros estão colocados ao contrário. Os livros não estão com a lombada para fora, mas mostrando os cortes das folhas, que são totalmente dourados. Como José de Sigüenza explicou no início do XVII, era desta maneira que se fazia para que os livros refletissem a luz da sala, a luz do conhecimento. Para mim, esta imagem é muito característica do mundo da cultura escrita da Idade Moderna, não só na Espanha e em Portugal, mas em todas as partes. Trata-se de um mundo distinto, porém igual, um mundo de alteridades. E a melhor maneira de imaginá-lo é esta: a imagem de um livro que é igual aos que eu conheço hoje, mas que está colocado de outra maneira, ao contrário. Tenho de descobrir por que está ao contrário. A explicação dada passava por buscar o reflexo material da verdade, que brilhava nas folhas do corte dos livros. Isso me levou, agora, a entrar em um território que é distinto: recorrer às categorias próprias da época para descrever uma prática concreta como a de colocar os livros ao contrário, algo que não era só Felipe II que fazia.

Portanto, a heterografia é uma maneira de dizer e de recordar que existe uma alteridade da cultura escrita, e é uma espécie de manifesto da vontade de insistir nessa alteridade. Sim, tratamos de livros, autores, público, leitura, palavra, imagem, mas a primeira coisa que temos de fazer é saber se essas palavras significavam a mesma coisa que significam hoje. Porque, possivelmente, não significavam o mesmo em todos os casos. Portanto, a ideia de heterografia supóe também chamar atenção para as práticas. Reconstruir as práticas supóe ingressar no território da alteridade da cultura escrita, oral e visual do passado.

Escrever essas heterografias foi também um tour de force. Só é possível compreender o trabalho que fiz como resultado de um convite especial, para um auditório também muito especial, o do Collège de France, um lugar onde podem ser feitas heterografias. É nesse sentido que os valores apontados por Andrea Daher — eficácia, manuscrito e tradução são heterográficos. E, ao afirmar que são heterográficos, se reconhece, ao mesmo tempo, o cânone imediatamente anterior. Além disso, insisto que é possível escrever de outra maneira, uma maneira que passe fundamentalmente pelas práticas, pois o heterográfico, assim como o heterodoxo, se reconstrói a partir de práticas. 
Andrea Daher: E o que a eficácia, o manuscrito e a tradução potencialmente trazem de heterográfico? Qual é a vantagem heurística desses três loci?

Fernando Bouza: Bem, em primeiro lugar, a eficácia teria a ver com o fato de que ler ou escrever ou nomear têm um efeito criador. Na época moderna, amaldiçoar um filho podia significar que, de fato, o filho ficasse amaldiçoado; ler o nome de um herege podia provocar algum efeito maligno sobre a pessoa que o lê, inclusive físico, mas não um efeito intelectual, nem moral. A isso, chamaríamos eficácia. São reflexos de um mundo de práticas de leitura que não passam pela leitura racional da tópica homo typograficus de Marshall McLuhan. Quer dizer, são formas de apropriação dos textos que não têm a ver com o intelecto ou com a razão, mas que têm a ver com os sentidos. É uma chamada ao sensorial na leitura. Por exemplo, livros para recém-nascidos. Por acaso eles os podem ler? Evidentemente, não. Mas esses livros - geralmente versóes abreviadas dos evangelhos — têm eficácia por si sós. A acumulação de casos mostra que, tanto em meios cortesãos como em meios "populares", em meios letrados e náo letrados, foram registrados usos nos quais a escrita relacionava-se com os sentidos e não com a razão. Por exemplo, a prática de ingerir textos, de comê-los, é algo que para nós hoje em dia é uma doença - a ingestão de papéis escritos está descrita tecnicamente como uma doença, uma forma de transtorno alimentar, conhecido como "transtorno de pica”. Há uma personagem da Comédie de Honoré de Balzac (1840), Pierrette Lorrain, que come papéis, que come folhas de livros, porque sofre clorose férrica, ou seja, uma forma de anemia. A tinta ferrogálica a satisfaz, pelo fato de a jovem padecer de falta de ferro. Mas comer papéis antes do século XIX não era descrito como uma doença, era na verdade uma prática; criticada, talvez, mas uma prática de fato bastante ampla.

Em segundo lugar, o mundo do manuscrito teria a possibilidade de refletir estruturas abertas na transmissão. Há pouco dizíamos que o impresso fixa o texto, que o torna estável em sua forma, ao mesmo tempo que o difunde e o preserva. Agora, é preciso lembrar que o texto manuscrito é um texto mais instável em sua forma, mas por isso mesmo mais acomodável. Neste sentido, o manuscrito poderia ser definido pela sua capacidade de adaptação à circunstância. Por exemplo, se fizéssemos uma operação simples: suponhamos que a professora Andrea Daher desse para que fosse copiado um texto qualquer ao professor João Fragoso, e que este o copiasse de punho e letra, e que sua cópia fosse passando pelas mãos de todos os que estão nesta sala, e fossem feitas assim sucessivas cópias até trinta. Se comparássemos o texto original da professora Daher com o texto recebido no final, como vocês podem supor, o texto possivelmente não seria igual. Entretanto, se fizermos trinta cópias impressas do mesmo texto, todas elas serão iguais ao original composto. Isso quer dizer que, em uma tradição manuscrita, é possível cometer erros em cada nova cópia, mas também incorporar novas formas de mudança que podem significar melhorias: comentários, glosas, correçóes, explicaçóes etc. Ou seja, o mundo da cópia manuscrita é um mundo acomodável. Por isso, 
para as instituiçóes e os grupos sociais, são muito importantes os interesses envolvidos, que devem se adequar a espaços e tempos distintos. Um exemplo disso são as ordens religiosas. Elas são, obviamente, uma instituição comum na Idade Moderna, mas têm espaços muito distintos. As necessidades de uma missão nas Filipinas não são iguais às necessidades de uma missão nas Canárias, em Cabo Verde ou na Bahia. São completamente diferentes. Portanto, os manuscritos podem manter a estrutura central, se ajustando à ordem original, mas podem se adaptar circunstancialmente a distintas realidades locais. Quanto ao espaço, o mundo imperial é um mundo manuscrito, é claro. Do mesmo modo acontece com as variáveis de tempo, os conhecimentos ou os saberes que devem ser adequados às mudanças, com o passar do tempo. É o caso do mundo da corte. Geralmente, pensamos esse mundo cortesáo como um mundo bastante estático. Imaginamos, por exemplo, a corte imperial vienense dos Habsburgo como uma corte absolutamente regulamentada, um espaço onde todo mundo sabia o que tinha de fazer a cada dia, a cada momento. Isso é, ao meu ver, um pouco efeito dos filmes de Luchino Visconti. Ao contrário, a vida de corte do Antigo Regime era um tipo de vida extremamente circunstancial, variável, na qual tudo mudava. É certo que algumas coisas que consideramos efêmeras duravam muito tempo, como os cadafalsos de D. Sebastiáo, que foram conservados durante décadas em Lisboa porque não foram destruídos. Mas, em geral, a memória da corte é muito frágil e nem tudo se encontra nas bem conhecidas etiquetas cerimoniais. Quando ocorria algo na corte que era um pouco complicado por ser incomum, era preciso procurar com toda urgência uma pessoa mais velha, que tivesse vivido ali por muito tempo, para perguntar como se organizava essa ou aquela cerimônia. Resumindo, na corte, muitas coisas mudavam e não eram forçosamente previstas, pois a memória da corte pode ser muito frágil. Nesse mundo de circunstâncias que mudam, é preciso uma memória muito local. A cópia manuscrita se acomoda muito bem a esse mundo de mudanças e em contínua transformação. Vejamos um exemplo de como, em 1548, 1592 e até 1621, o mesmo texto foi sendo modificado para se acomodar às mudanças da corte. O exemplo do qual lhes falo é clássico, são as chamadas Instruçóes de corte, que João de Silva, conde de Portalegre, compôs em 1592 sobre a base de outras instruçóes escritas por Juan de Vega em 1548. Ambas seriam novamente adicionadas em 1621 a um novo texto de corte. Por mais que tenham chegado a ser impressas, sua difusão, muito abundante, foi feita através de cópias manuscritas. Um dos capítulos dessas Instruçóes se dedica, por exemplo, ao que deve ler o jovem cavalheiro que vai à corte. Vemos, neste caso, a circunstância do agora, do hic et nunc, que o impresso não proporciona porque é permanente e náo circunstancial. Em 1548, se recomenda ao jovem cavalheiro que vai à corte que leia livros de santos e de história, como também que ele fale com os velhos soldados. Em 1592, esse mesmo capítulo traz o que Juan de Vega escrevia em 1548 e agrega o texto de Juan de Silva que diz, então, que o jovem cavalheiro que vai à corte terá de ir ao encontro dos privados, e que fará muito bem em ler Tácito. E, em 1621, com o texto de Silva adicionado ao de Vega, o que se diz é que o cavalheiro quando chegar 
ao palácio deve pretender falar com o valido - dos viajantes soldados de 1548 ao valido de 1621, passando pelos validos de 1592. Quanto às leituras, há de se ler poesia - das histórias e vidas de santos (1548) a Góngora (1621), passando por Tácito com seus ecos lipsianos (1592). Aqui vocês têm, em três cenas sucessivas, uma completa história cultural da corte espanhola. O manuscrito tornou possível que o mesmo texto se acomodasse a três circunstâncias distintas. Por sua vez, o texto impresso de Baldassare Castiglione era o mesmo em 1548, em 1592 e em 1621. Não há referências aos validos no texto de seu Il cortegiano (1528). Este foi um texto que sempre gozou de grande estima, que sempre foi considerado muito importante, mas, do ponto de vista das necessidades de quem vai ao palácio e tem de viver nele, não responde às novas circunstâncias da vida palaciana. Evidentemente, o texto fala da dissimulação, da sprezzatura, de um mundo de oralidade no qual se "habla delgado". Tudo isso é certo, mas Il cortegiano não tem resposta para a nova realidade dos privados nem, mais tarde, para a do valido. Contudo, essas instruçôes manuscritas que os pais escrevem para os filhos que vão à corte podem ir se adaptando com o tempo, mediante adições de novas perguntas para novas questôes. Portanto, quanto ao manuscrito, a tensão com o impresso é a tensão de uma escrita que é adaptável.

Por último, quanto à tradução, mais uma vez teríamos de pensar o estatuto do autor, esse estatuto heroico de alguém que escreve um livro para que os leitores o desvendem - por exemplo, lemos a obra de Braudel e, no fundo, tentamos compreender sua mensagem: o que Fernand Braudel quer nos dizer? $\mathrm{O}$ autor heroico é um tipo de autor individual, perfeitamente reconhecível, e que faz de sua escrita, de alguma forma, um manifesto. Esse tipo de autor, heroico ou heroicizado, provém do Iluminismo. Antes, os autores não gozavam de um estatuto tão preeminente, por mais que, pouco a pouco, ele fosse sendo construído. Querer chamar a atenção sobre o tradutor em vez do autor pressupóe falar de usos indistintos da escrita e descobrir algo que acho sumamente interessante: alguns acreditaram que a tradução era uma forma superior de escrita, uma forma "senhorial" de escrita na qual o tradutor, como um general militar, vai se apoderando do intelecto do autor cuja obra traduz, dominando seus conceitos ao passá-los para a oura língua. Esta ideia da traduçáo "senhorial" é, para mim, especialmente interessante. Durante a pesquisa, pude descobrir que, ao reconstruir os usos da época, traduzir era considerado, em determinadas ocasiōes e para determinados gêneros, uma forma superior à escrita de uma obra. Assim, rompia-se a ortografia do período, rompia-se, através de usos e de práticas, o reconhecimento da autoridade da época.

Andrea Daher: Todos aqueles que conhecem a sua obra sabem como ela se inscreve no interior de formas materiais, que são formas de acumulação e de conservação da escrita e da imagem que constituem os arquivos e as bibliotecas, os museus, as galerias etc. Nela, esses espaços ganham uma significação política e uma dimensão social que costumam estar ausentes do trabalho mais geral dos historiadores. Como incluir, entáo, essa lógica do arqui- 
vo, muitas vezes desfeita, no trabalho historiográfico? Qual é a importância da inclusão da lógica do arquivo no trabalho historiográfico? Aproveito a ocasião para perguntar, ao final, qual foi a sua impressão da Biblioteca Brasiliana José e Guita Mindlin, onde esteve recentemente, em São Paulo.

Fernando Bouza: Quero insistir na ideia de que os "depósitos do saber" construídos durante a Idade Moderna — mas também os de hoje, entre eles a biblioteca Mindlin ou qualquer outra biblioteca — não são espaços inocentes. São frutos de uma escolha, são, por si só, uma construção. Mas, me atreveria a dizer que isso se dá não apenas por eles serem a voz de um grupo ou de outro, mas porque "fazer" um arquivo implica guardar determinados papéis e não guardar outros, e isso com uma ordem particular e específica. Ou seja, aqui surge novamente a ideia de pensar por casos, reconstruindo suas categorias e colocando-os em seu horizonte, de modo a compreender realidades que são distintas das nossas. Mas vejamos um exemplo, partindo do fato de que, sempre que existam opçóes, pode-se buscar uma estratégia, há a possibilidade de uma intencionalidade. Visitei também, no Rio de Janeiro, o Real Gabinete Português de Leitura, que é absolutamente fascinante. Lá, me lembrei de uma das minhas manias, quase patológica, que é a de querer saber qual é o manuscrito ou o impresso com o primeiro registro bibliográfico e qual é o último. Qual seriam o primeiro e o último dos livros dispostos no Real Gabinete Português de Leitura do Rio de Janeiro? Falo isso porque, como vocês sabem, Felipe IV de Habsburgo (D. Felipe III de Portugal) tinha uma grande biblioteca em seu palácio do Alcazar de Madri. Seu avô, Felipe II, tinha fundado a grande biblioteca do Escorial, mas Felipe IV criou uma biblioteca em línguas vernáculas em seu Alcazar. Então, me deixando levar por esta minha ideia peregrina de querer saber qual era o primeiro livro e qual era o último, me deparei com a informação de que, segundo o inventário da biblioteca, de 1637, o primeiro livro na ordem tipográfica de registro era um livro intitulado Excelencias de la Monarquia e Reynos de España (1597), de Gregório López Madera - o que não é nada mal como "primeira pedra” para o hipotético edifício textual da real biblioteca. E o último livro de todos é Utopía, de Thomas Morus, traduzido ao castelhano. (Perdoem-me por dizer isso, mas Jorge Luis Borges é um notário, não é alguém que fabule.) Uma biblioteca de 1637, na qual, segundo seu próprio inventário, o primeiro livro é sobre a monarquia de Espanha e o último sobre utopia: para mim, isso não pode ser um fato casual, há uma intencionalidade pragmática nessa disposição. Acho que nisso fica refletida a ideia de que arquivos e bibliotecas não são inocentes depósitos do saber. Sem dúvida, talvez o rei Felipe IV não fosse o responsável dessa disposição, mas, sim, um bibliotecário, cujo nome era Francisco de Rioja. Ele ordenou os livros de uma forma e não de outra, como François Grudé, senhor de La Croix du Maine, que em seu livro Bibliothèque (1584) propóe a biblioteca ideal para o rei da França, em que elenca cem inscriptions sob as quais se deveriam reunir todos os livros. A primeira inscription relacionava-se ao Deus 
criador do Gênesis e a última, claro, ao Apocalipse. Aí encontra-se encerrado o universo. A ordem dos livros, como diz Roger Chartier, é a imagem do universo. Por isso eu digo que arquivos e bibliotecas não são inocentes.

Por outro lado, a minha relação com livros, com bibliotecas e arquivos é uma relação muito, muito cara e muito particular. Em certa ocasiáo, uma pessoa me disse que o que eu fazia era um pouco perverso. A palavra é forte, mas vocês veráo que a perversão é muito inocente. Esta colega me disse que eu procurava no arquivo o que os demais procuram na biblioteca e que, ao mesmo tempo, procurava nas bibliotecas o que os outros procuravam no arquivo. Eu respondi que, se essa era a minha perversão, eu era quase um santo. Mas, sim, na minha relação com os livros pode existir algo dessa mudança de lugares na hora de fazer as perguntas. A minha confiança nos arquivos é, claro, enorme. Quero insistir nessa máxima: "arquivo, arquivo e arquivo", com horizonte, sem horizonte, com usos, sem usos. O arquivo é não é um lugar inocente tampouco, mas é um lugar maravilhoso. Pessoalmente, não sou um grande leitor de literatura, talvez até um mau leitor de literatura, apenas de romances policiais - agora eu estou lendo um que se passa aqui no Rio de Janeiro, do delegado Espinoza, de Luiz Alfredo Garcia Roza, e, então, vou pelas ruas da cidade e me surpreendo, dizendo “ah, esta é a avenida Atlântica!". Eu já li muita literatura contemporânea, mas não leio mais, porque para mim o lugar da fábula, o lugar do riso, o lugar da emoção é o arquivo e a biblioteca. Os relatos que posso encontrar aí são verdadeiramente maravilhosos. E não sou capaz de ler o último ganhador do prêmio Goncourt!

Andrea Daher: Mas, ao mesmo tempo, essa ideia de conhecer o primeiro e o último livro de uma biblioteca é bastante fabulosa também. Aliás, ela daria um romance igualmente "fabuloso". E, nele, o personagem central haveria de ser Fernando Bouza.

Fernando Bouza: Não! Vejam, a história de "romance" vinculada à biblioteca mais bonita que eu já vi — não tem nada a ver com isso, mas eu vou contar para vocês — tem a ver com o mundo das fichas. Lembram das antigas fichas de catálogos? Na Biblioteca Nacional da Espanha, em Madri, havia uma enorme sala de fichários. Dois andares de salas de fichários. Um labirinto. E havia pessoas que deixavam mensagens entre as fichas. Se você estivesse procurando uma obra, poderia encontrar, por casualidade, alguma dessas mensagens. Por exemplo, na ficha de Diário de um sedutor, de Søren Kierkegaard, por se tratar de um romance de amor, era possível encontrar uma mensagem que dissesse: "Senhorita aventureira, se deseja, estarei no café tal dia e tal hora”. Eu não sei onde se deveria procurar a resposta. Afinal, deixar mensagens em fichários era, evidentemente, um jogo particular.

De qualquer forma, esta história fala sobre a biblioteca como um lugar em que se brinca, um lugar de opçóes. Seria injusto tentar reduzir toda a estratégia e eliminar a parte da brincadeira e do prazer. Eu gostaria de insistir nisso: por vezes, leio trabalhos sobre bibliotecas 
ou arquivos nos quais se propóe que existem estratégias e intenções políticas que não chego a ver. Não sei se vocês perceberam que, para uma determinada história cultural, existe uma tendência para encontrar "mensagens secretas" em qualquer tipo de prática. Contra essa tendência, acho que é necessário estar alerta e ser prudente, como nos mostra a história do colecionismo de pinturas.

Atualmente estou trabalhando sobre as galerias de pinturas dos descendentes de D. Antonio Prior do Crato: é uma coleção valiosa, mas não vou necessariamente encontrar ali um manifesto de sua demanda pelo trono português. Parece que os seus proprietários gostavam, simplesmente, das pinturas; ou, talvez, eles quisessem imitar os grandes colecionistas principescos. Mas, é claro, não tenho de encontrar uma chave, porque a cultura não está sempre escrita à la clef para o período da Idade Moderna. Nesse ponto acho que estáo sendo feitos alguns excessos. Mas, é claro, existem arquivos e bibliotecas sobre os quais cabe dizer que foram usados intencionalmente. Naquela época, não só as monarquias tinham arquivos, mas também as casas nobiliárias, as instituiçôes eclesiásticas, as comunidades ou, ainda, os particulares. E alguns arquivos foram mobilizados como recurso de luta política de seus proprietários ou, simplesmente, como uma forma de garantir a subsistência deles. Por exemplo, os descendentes de D. Antônio, no século XVII, tiraram grande vantagem do arquivo do Prior pretendente, tanto abrindo o arquivo para os eruditos, que estavam interessados em conhecer seus acervos, quanto recordando os antigos vínculos que uniam sua casa aos potentados da Europa; ou ainda, de forma mais ousada, ameaçando publicar alguns documentos que poderiam ser comprometedores. Resumindo, foram utilizados, de forma muito concreta, todos os recursos da memória que o arquivo familiar antonino lhes permitiu. Algumas das famílias da nobreza portuguesa que permaneceram fiéis a Felipe IV depois de 1640 fizeram coisas extraordinárias, como dar à imprensa seus arquivos, ou publicar o arquivo inteiro dos papéis que conservavam. Martim Soares de Alarcão, da casa do condes de Torres Vedras, publicou Relaciones (1656), em que afirma que "chegando a colocar em ordem os papéis que foram encontrados em Castela pertencentes a varonia, com o objetivo de guardá-los, pareceu mais conveniente os fazer estampar”. A explicação que Soares de Alarcão sugere é que os papéis servirão como exemplo a outros, que todos poderão conhecer sua lealdade e, além disso, "para a maior segurança dos próprios papéis". Em meados do XVII, o arquivo não era monopólio do poder "estatal", como é no mundo contemporâneo. Isso me lembra uma passagem de Ernst Jünger, que em Strahlungen [Radiaciones. Diarios de la Segunda Guerra Mundial] (1949) descreve a sensação de enorme poder sobre a França quando se está na sala dos catálogos da Bibliothèque Nationale de Paris. Esta ideia de ter conquistado um país inteiro ao ocupar seus arquivos não parece ser uma possibilidade de mesma extensão naquela época - eu ia dizer "nossa", mas talvez seja muito possessivo — , digo, para os séculos XVI e XVII, porque havia grandes arquivos, mas também uma constelação de pequenos arquivos, de arquivos pessoais, nos quais se conservam as histórias de suas vidas. 
Em São Paulo tive a oportunidade de ver alguns desses arquivos pessoais desse período, reduzidos apenas a um volume, no qual se reúnem certificados de soldados, de oficiais ou de clérigos e que são testemunhos de vidas inteiras. Aliás, pude também consultar uma documentação sobre assuntos impensados, com notícias de Miguel de Noronha sobre o comércio de "alcatifas" entre Goa e os conventos de Lisboa. No Instituto de Estudos Brasileiros, tive acesso a uma excepcional coleção de manuscritos. Achei a Mindlin uma biblioteca muito boa. Vi peças únicas, que nunca tinha visto antes - e, creiam, vi muitas coisas ao longo da minha vida. Por exemplo, panfletos portugueses de propaganda, impressos em castelhano feitos em Viena, que chamaram muito a minha atenção, e que até agora não estavam no meu catálogo de papéis sobre a Restauração, como também a coleção de impressos holandeses, na qual existem raras peças. Uma coisa interessante é que eu pude consultar peças de polêmica e propaganda portuguesa posteriores a 1640 que náo foram pedidas pela Coroa, mas diretamente por particulares. Livreiros que publicam, por sua conta, uma série de panfletos (esses panfletos têm um interesse como mercadoria destinada a um público leitor que quer estar informado sobre o que está acontecendo). Achei extraordinário o impresso conservado na Mindlin, publicado em Lisboa, "que escreveo o Marques de Montalvam, sendo Viso Rey do Estado do Brasil, ao Conde de Nassau" (1642), incluindo os cumprimentos do holandês pelos acontecimentos de 1640 (questão que Stuart Schwartz conhece bem). Portanto, a Brasiliana de Guita e José Mindlin tem peças muito, muito boas.

JaCQueline Hermann: Queria aproveitar a sua presença, então, já que o assunto é arquivo, para comentar um pouco a criação do Arquivo General de Simancas, exatamente durante o período do reinado de Felipe II. O que isso representou, o que podia representar numa concepção de poder que está na sua obra? Queria que você pudesse aproveitar este momento para falar um pouco da importância da criação desse arquivo e do projeto de poder que estava ali estabelecido.

Fernando Bouza: Felipe II fundou o arquivo da Embaixada da Espanha na Santa Sede, em Roma. Os outros arquivos de que cuida, continuamente, são arquivos prévios. Concretamente, Simancas é um arquivo anterior. Ele recebe uma nova organização, na forma de ordenanças, em tempos de Felipe II. O monarca se interessa pessoalmente pela matéria dos arquivos e, durante a sua estada em Lisboa (1581-1583), ele visita a Torre do Tombo e ordena que copiem os seus estatutos, que têm um importante impacto nas ordenanças de Simancas. Ele também se interessa pelo arquivo da Coroa de Aragáo, se ocupando de sua instalação e da recepção de novos fundos. Mas o arquivo fundamental de Felipe II é Simancas. É um arquivo que tem uma categoria extraordinária, a partir do momento que o seu responsável é secretário real. Portanto, não é só um lugar de erudição, pois o secretário Diego de Ayala faz parte do organograma dos secretários reais. Quer dizer, Ayala em Simancas é táo secretário 
do rei quanto Mateo Vázquez em Madri. E, efetivamente, o arquivo não é só um lugar de erudição porque tem uma vinculação com a prática de governo.

Para mim, o arquivo de Simancas supóe, por um lado, a memória da monarquia, de uma monarquia que rapidamente se escriturizou e que tira proveito disso. Em algumas de suas seçôes, especialmente "Patronato real", está depositada a história dos direitos da monarquia. Neste sentido, seria um lugar da memória histórica da própria Coroa. Por exemplo, a maior parte da documentação que, em 1580, Felipe II mobiliza para reivindicar os seus hipotéticos direitos ao trono — remetendo-se, antes de mais nada, à crise de 1385 — provém de Simancas.

Ao mesmo tempo, o arquivo é um lugar de memória e é um lugar de despacho de governo. E isso é extraordinário. Porque existem outros lugares onde parece que se cumpriu mais a função de memória dos direitos e privilégios da monarquia. Entretanto, em Simancas, ambos os usos se cruzam, o comemorativo e o prático. Nesse sentido, Felipe II como "Rey Papelero" tem um lugar especial em Simancas.

Andrea Daher: Gostaria que você nos falasse um pouco do panorama mais geral da historiografia contemporânea, em termos das interlocuçóes mais fortes do seu trabalho. É claro que, como foi dito, as pesquisas em arquivos e bibliotecas sendo uma marca muito forte nos seus livros, por vezes as interlocuçóes parecem estar mais apagadas. Sabemos da sua forte relação com o trabalho de Roger Chartier, não fosse pelos interesses comuns em torno da cultura escrita e pela história do livro; sabemos também de sua forte interlocução com Jean-Frédéric Schaub, não fosse pelo interesse de ambos em unir, ou melhor, em apagar, digamos assim, as fronteiras entre história cultural e história política. Mas há também toda uma série de interlocuções com historiadores portugueses, como António Manuel Hespanha e, talvez mais recentemente, com historiadores brasileiros. Você poderia traçar um panorama dessas interlocuçóes hoje, em relação ao seu trabalho?

Fernando Bouza: A ideia de interlocução me preocupa muito. Em primeiro lugar, no começo desta sessão, quando falava da recuperação de horizontes, estava fazendo também um juízo sobre a situação da historiografia contemporânea. A meu ver, insisto, não voltaremos a fazer uma história fundamentada na noção de progresso, mas, sem dúvida, será recuperada certa ideia de "horizonte", depois de tempos de pós-modernismo. Pouco a pouco, creio que estão sendo recuperadas essas linhas norteadoras, algo que, pessoalmente, acho interessante.

Em segundo lugar, meu trabalho atual tem muito a ver com as ideias de comunicação política e de esfera pública. No fundo, o que eu gostaria de fazer agora é uma história da opinião. Em que momento os que governam tiveram interesse em saber o que os governados diziam? Em que momento os governados souberam que essas opiniōes podiam ser impor- 
tantes? E como isso serviu para dinamizar a história? Ou seja, estou mais interessado na análise de efeitos, na mudança ao longo do tempo. Contudo, me preocupa bastante que o meu tipo de escrita não seja mais simples. Fazendo aqui a minha própria crítica, creio que exijo muito do leitor, pedindo que seja ele quem chegue às conclusôes em sua própria análise. Mas, isso tem a ver com a minha educação, quando se evitava a ideia de meramente administrar doutrina. Nós, pesquisadores educados na década de 1980, fomos vacinados contra o atualismo. Isto teve o efeito de me lançar aos estudos de casos, com forte base documental de arquivo, para reconstruir os casos de forma mais completa e complexa. Talvez também tenha trazido a consequência de um tipo de fuga para a frente, através da erudição e das notas de rodapé, sem quase me atrever a apresentar conclusóes analíticas. No fundo, fui educado para fazer dos leitores meus cúmplices, para que sejam eles que tirem as conclusóes, recusando qualquer papel doutrinário da escrita da história.

Andrea Daher: De fato, à leitura de seus livros, há sempre a surpresa da enorme fragmentação da estrutura, da perspectiva narrativa, mas também teórico-metodológica. Há, sem dúvida, os efeitos da sua formação nos anos 1980 e, nesse sentido, este talvez não seja exatamente um aspecto unicamente da sua escrita, mas muito mais de uma escolha estratégica.

Fernando Bouza: Exatamente. De alguma maneira a minha geração foi educada para escrever assim, entretanto, para falar de outra maneira. Na sala de aula parece possível expor de cronologias mais amplas, falar em termos de consequências, coisas que não eram passíveis de serem expressas na escrita da história. A minha vontade de envolver performativamente o leitor na conclusão das minhas próprias pesquisas tem algo a ver com o que os autores dos séculos XVI e XVII faziam. Quer dizer, eles contavam com o que o leitor já sabia. Assim, eram os leitores ou as leitoras que concluíam seus textos. Tendo sido pessoalmente vacinado contra o atualismo, fui educado na necessidade de não transmitir doutrina através da escrita da história, como disse. Diante dos que escreviam para proclamar, por exemplo, "estas são as causas do absolutismo", fui ensinado que devia dispor os materiais, de tal forma que fosse o leitor quem concluísse "estas são as causas do absolutismo". Isso faz com que, possivelmente, a leitura de meus textos não seja simples.

Por outro lado, minha relação de dependência com as fontes primárias de arquivo só é compreensível levando em conta a enorme riqueza dos arquivos na Espanha e em Portugal. Eu só pude me permitir o luxo de conhecer esses casos e escrever as suas histórias porque existe Simancas, a Torre de Tombo etc. Porque existem esses lugares absolutamente maravilhosos onde, como dizia antes, as melhores histórias do mundo esperam para serem contadas um dia. Essa enorme riqueza, possivelmente, reforçou em mim o efeito geracional antes mencionado e ajudou a tornar ainda maior a minha insistência na base documental e a minha vontade de transferi-la. É claro, eu que digo que nenhum arquivo é inocente, tenho de reconhecer que os 
textos tampouco o são, e que, no final das contas, posso dizer que me desloquei do mundo português ao mundo de uma monarquia que é pluricontinental, um mundo de monarquias ibéricas pluricêntricas. Neste sentido, comecei fazendo história de Portugal e me deparei com o fato de que entre 1580 e 1640 não havia uma corte no reino. E desta ausência passei à corte régia de Felipe II e, nela, à história da comunicação. E desta, sempre com critérios de história cultural e política, passei à história da opiniáo pública. Agora, digamos, o meu mundo não só é um mundo ibérico, mas é também um mundo americano, filipino, indiano etc. Neste movimento, eu acho que foi de enorme importância o impacto não da historiografia espanhola sobre a portuguesa, mas, ao contrário, da historiografia luso-brasileira sobre a espanhola e a europeia. Uma das coisas que mais mudou na historiografia modernista na Espanha é, precisamente, ter começado a romper as barreiras entre escrever a história da Espanha e a história da América. Porque em muitas universidades espanholas, entre elas a minha, existia uma forte diferença entre os historiadores americanistas e os historiadores gerais da Idade Moderna. Essa situação mudou, em grande medida pelo efeito da história do mundo atlântico e, especialmente, pelo forte impacto entre os historiadores da obra de António Manuel Hespanha. Foi ele quem trouxe até Portugal e, mais tarde, até o Brasil boa parte da historiografia espanhola. A mudança supóe que, se eu agora escrevo um artigo sobre Felipe II, posso incorporar cenários como as Ilhas Salomão, no Pacífico, ou São Sebastião do Rio de Janeiro, um povoado de que o Rei Católico recebe notícias desde finais da década de 1550.

Quando apresentei a minha tese, em 1986, sobre D. Felipe I e Portugal em 1580, fiz muito poucas observaçóes sobre o Brasil, por questôes documentais, mas também porque uma aproximação brasileira teria sido imprópria para uma tese lida num Departamento de História Moderna, e não de História da América. Portanto, de fato, a minha relação com estas outras historiografias aumentou muito porque o impacto do luso-brasileiro da nova maneira de interpretar a relação entre Brasil e Lisboa (e também a Índia) foi enorme na historiografia espanhola.

É possível que os primeiros passos tenham sido dados a partir da Espanha para Portugal. Mas, no final das contas, a historiografia modernista espanhola aprendeu história da América através de Portugal e do Brasil. Assim poderia ser descrita a minha situação atual. Me atrevo a dizer que devemos continuar fazendo história através de casos. Temos de seguir trabalhando no arquivo, temos de recuperar horizontes de uma duração mais longa. Nunca devemos renunciar à análise, e temos de romper as barreiras disciplinares, da mesma forma que se romperam as barreiras entre cultura, política e história da arte. Possivelmente, para a história modernista espanhola, a mais difícil de romper foi a fronteira da história da América, apesar de permanecer vigente ainda para muitas outras.

Weder Ferreira: Gostaria que você pontuasse a importância da constituição de Cádiz e da revolução do Porto no contexto editorial da Península Ibérica, e dissesse de que forma esse contexto influenciou as outras nações na América Latina, por exemplo. 
Fernando Bouza: Cádiz é o mundo da constituição política e da liberdade de imprensa. Por isso, Cádiz seria de fato o final dessa história que quero reconstruir, na qual entram em circulação impressos, manuscritos, imagens e vozes. A liberdade de imprensa é especialmente importante em Cádiz porque se vincula a uma nova maneira, cidadã, de estabelecer a relação entre os governantes e a comunidade, os governados. Entretanto, isso não supóe que não seja preciso desentranhar primeiro a tópica que une liberdade e imprensa, uma das mais poderosas, e que, além disso, joga de forma maliciosa porque, digamos, age sobre nós quase sem que saibamos, como uma forma de pré-conhecimento. Seria importante fazer uma reconstrução do maior número possível de narrativas relacionadas com a tópica da liberdade da imprensa, em torno dos anos de 1808, 1810 e 1812. São momentos nos quais, na Espanha, se consegue a liberdade de imprensa e se estabelecem pela primeira vez distintas imprensas permanentes em lugares nos quais, até aquele momento, não se dispunha delas, como o Rio de Janeiro, Montevidéu ou Valparaíso do Chile. Tanto em Cádiz como nestes lugares novos, são forjadas narrativas para serem impressas, nas quais se defende a ideia de que antes da chegada da imprensa imperava o silêncio, o vazio comunicativo. Nisso coincidem, por exemplo, os relatos uruguaio e chileno. Mas, como vocês sabem bem, a imprensa chega a Montevidéu a partir do Rio de Janeiro, como um presente que a rainha Carlota Joaquina envia aos monarquistas de Montevidéu, que são partidários do absolutista Fernando VII. Os fernandinos montevideanos proclamam que, graças à imprensa, podem finalmente se expressar, o mesmo que disseram os chilenos de Valparaíso (apesar de serem emancipadores, e não absolutistas). No final das contas, a tópica da liberdade da imprensa como sinônimo de expressão e verdade tem a ver com o acervo conceitual do Iluminismo, que supóe que, antes da chegada da imprensa, não é possível a plena comunicação. Pessoalmente, responderia que não, porque antes da imprensa era possível recorrer a sistemas efetivos de difusão manuscrita, como os da scribal publication, ou seja, a circulaçáo mediante traslados e cópias manuscritas de notícias e conceitos. Sem dúvida, a chegada da imprensa permite a geraçáo de termos de comunicação política mais fluentes, mas não creio que se possa dizer que as sociedades do Antigo Regime que careciam de imprensa estivessem condenadas ao silêncio em questóes de comunicaçáo política. E quando digo silêncio, poderia dizer ignorância. Dito isso, convém lembrar que, é claro, o papel desempenhado pela imprensa nos movimentos que rompem com o Antigo Regime no começo do século XIX foi extraordinariamente importante, na Cádiz liberal da Guerra de Independência ou nas colônias espanholas da América em tempos dos movimentos emancipadores. É impressionante o volume de textos impressos em espanhol que saíram de centros tipográficos dos Estados Unidos, como da Filadélfia, ou em algumas antigas ilhas do Caribe inglês, onde também se imprime em espanhol para abastecer a América espanhola. Teríamos de estudar muito melhor essa propaganda impressa para as Índias, assim como - e me permitam que insista nisso - a construção e a difusão do mito libertador da imprensa. No meu entender, esse mito tem uma forte repercussão sobre 
o imaginário coletivo. Pelo menos, foi o que me pareceu aqui no Brasil, onde se dá, é lógico, uma enorme importância ao estabelecimento de uma imprensa permanente com a chegada da corte dos Bragança em 1808. Em certas ocasióes, tenho a sensação de que, antes dessa data, havia uma espécie de "menos valia comunitária". Não posso entrar nessa questão, mas creio, sim, que o estudo dos circuitos da scribal publication no Brasil dos séculos XVI e XVII poderia ser verdadeiramente revelador. Claro, isso também me levou a questionar por que náo havia uma imprensa permanente no Rio de Janeiro, ou na Bahia, antes dessa data. Em qualquer caso, hoje, heterograficamente, sabemos que a não existência de imprensa não supóe a impossibilidade de conhecer, expressar, lembrar ou comunicar mediante vozes, imagens e manuscritos. Sem dúvida, a imprensa favorece uma difusão massiva e perdurável dos textos, mas isso não supóe que antes dela as populaçóes estivessem condenadas ao vazio do silêncio e da ignorância.

Andrea Daher: Essa é uma tópica historiográfica pós-romântica e pós-iluminista. Por exemplo, no Brasil do século XIX, a publicação de dicionários, de gramáticas e de vocabulários em língua tupi partia exatamente desse pressuposto de um "vazio" que se estendia desde o passado colonial, que devia ser preenchido com essas reediçóes ou impressóes de manuscritos, de modo a produzir uma presença dessas línguas indígenas então “inaudíveis”.

Fernando Bouza: Em vez de lidar com esse "vazio", lidar com a voz abriria possibilidades para pensar as coisas de uma forma muito distinta. O que é preciso urgentemente é um estudo completo, recorrendo todos os relatos da chegada da imprensa a distintos lugares. A chegada da imprensa à Nova Zelândia, estudada por Donald Mackenzie, a Valparaíso com a publicação de La Aurora, a chegada da imprensa em Montevidéu, a chegada da imprensa no Rio... Sobre essas bases teríamos de observar as continuidades que os distintos relatos apresentam e sua dependência em relação à tópica ilustrada. Não há voz: estão condenados ao silêncio os que não falam como falavam os ilustrados, que falavam letra impressa, como se sabe.

João Fragoso: Nesse terceiro tópico, você se referiu a alguns temas que, particularmente, são caros para nós, pelo menos para uma parcela das pesquisas aqui desenvolvidas a respeito de monarquia pluricontinental. Essa é uma nova ideia que se está construindo, friso, sobre a relação entre conquistas e centros da monarquia, seja ela lusa ou hispânica. Enfim, gostaria que você falasse sobre o impacto dessa ideia de monarquia pluricontinental na historiografia contemporânea, e que desenvolvesse a questão, consequentemente, da possibilidade de negociação entre as elites, a elite das conquistas com as elites do centro da monarquia. E mesmo sobre o que redefine a própria ideia de unificação política, entre esses dois lugares. Isso redefine a ideia de um Estado absolutista que durante tanto tempo prevaleceu na nossa 
historiografia e, de alguma forma, ainda domina. Quer dizer, é um absolutismo que não só cerceava a presença de senhorios, numa sociedade policimodal na Europa, como também cerceava a própria possibilidade de as conquistas estabelecerem negociaçóes com os centros, no caso Lisboa e, mais adiante, no período ibérico, Madri. Para mim foi uma surpresa a atenção que uma literatura historiográfica espanhola voltou para essa historiografia luso-brasileira centrada nessa questáo da monarquia pluricontinental, na possibilidade dessas negociaçôes hierárquicas, enfim, negociaçóes entre conquistas americanas e centros europeus.

Fernando Bouza: Primeiro, quanto à monarquia pluricontinental, monarquia pluricêntrica etc., no caso espanhol houve uma influência dupla. A meu ver, na situação atual, tem-se uma dívida com a tradição anglo-saxá de John H. Elliott e o mundo da monarquia hispânica, na recuperação de seu aspecto plurisjudicional. De fato, o impacto não foi sentido só na Espanha. Lembro a vocês da proposta de Conrad Russell de lançar mão de um esquema para a Monarchia Britannica, para os Stuart do século XVII, no qual não se pode ignorar a influência da Monarchia Hispana tal qual havia proposto Elliott. Isso é interessante porque passava-se de um modelo de monarquia nacional inglesa a uma monarquia compósita, não muito longe do que tinha sido qualificado como "monstruosidade hispânica". Em suma, a dívida dos historiadores modernistas espanhóis com a obra de J. H. Elliott e sua interpretação das monarquias compósitas é enorme.

Em segundo lugar, a outra dívida importante é com a obra de António Manuel Hespanha, cujo impacto na Espanha foi muito grande, principalmente na polêmica sobre a existência ou não do Estado na Idade Moderna - uma polêmica de que ele participou de mãos dadas com alguns historiadores espanhóis como Bartolomé Clavero. Convém lembrar que esta polêmica internacional foi vivida na Espanha de uma forma muito intensa e próxima, com figuras como Bartolomé Clavero, António Manuel Hespanha ou Pablo Fernández Albaladejo diante de outros autores que insistiam na existência do Estado. O impacto da polêmica foi enorme e, de fato, chegou com força às aulas o eco das colocaçóes de Hespanha.

Ademais, creio que também se sentiu a repercussão de alguns historiadores da história econômica. Acho que tem um peso especial a obra de Zacarías Moutoukias e seus estudos sobre os pactos informais entre as elites rio-platenses e a Coroa espanhola, expresso, digamos, numa forma de manutençáo da lealdade em troca de enriquecimento por via de contrabando - até que a nova legislação dos Bourbon fizesse quebrar o pacto informal e, consequentemente, fincasse uma das bases do movimento emancipador. As teorias de Moutoukias foram importantes por seu impacto sobre redes comerciais, num mundo que superava as próprias fronteiras, digamos, jurisdicionais. E foi ele, lembro, a primeira pessoa que, há trinta anos, me falou sobre "pactos informais das elites", antes mesmo que eu pudesse conhecer a obra de Hespanha. Nesse ponto, a minha dívida com o americanista Murdo J. MacLeod e suas histórias de resistência/acomodação também é antiga. 
Como podem ver, é uma história que foi se consolidando pouco a pouco. Agora, nos últimos anos, se produziu uma conjunção de historiadores do Brasil, de Portugal e da Espanha, fruto da qual foram ampliados os espaços até a Ásia e, muito especialmente, até a América. Historiadores que, como Stuart B. Schwartz, reuniram experiências do que acontecia na Bahia, mas que não esqueciam o que acontecia em Évora ou em Sevilha. A nova historiografia sobre a Europa hispânica dos séculos XVI e XVII também foi importante, porque abriu o mundo ibérico para Nápoles, Antuérpia ou Besançon. Mas, sem dúvida, o salto até o Brasil foi produzido pelas mãos de historiadores portugueses, como Pedro Cardim ou Nuno Monteiro, cujo impacto na Espanha foi muito forte. A intensificação dos contatos com a historiografia portuguesa foi muito grande e, pelo menos na minha experiência, o contato com a historiografia brasileira sobre o período dos Felipes foi, até agora, através de Portugal, vocês sabem disso.

Não é assim para o campo da historiografia cultural, no qual Paris, talvez, tenha tido um papel tão importante quanto o de Lisboa para os estudos políticos, institucionais ou sociais. Eu olho ao mesmo tempo para Paris e para Lisboa. Em todo caso, as obras de António Manuel Hespanha, Nuno Monteiro, Pedro Cardim, Angela Xavier e tantos outros me levaram a novos horizontes. Eu aprendi muito com eles. Vocês sabem que as relaçôes hispano-portuguesas são complexas, complicadas, e foram cometidos alguns erros em matéria de política cultural. Concluindo, é comum pensar numa historiografia espanhola forte que se expande para outras historiografias, mas, nesse caso, acreditem em mim, o impacto dos historiadores modernistas portugueses sobre a história que está sendo feita sobre a monarquia hispânica dos séculos XVI e XVII foi absolutamente crucial. E, através de Portugal, no meu caso, recebi também o impacto do Brasil.

Andrea Daher: Quanto à sua agenda de estudos, sobretudo sobre o período filipino, você tem afirmado querer defini-la através de alguns conceitos-chave que abririam campos potenciais de pesquisa. Um desses conceitos que reorganiza um campo potencial de trabalho, como dizia João Fragoso, é o de negociação. Ele pode levar a uma crítica, talvez velada, à noção de globalização, que seria menos apta do que a categoria de "mescla" para dar conta de circulaçôes culturais, de mestiçagens ou de outros fenômenos sociais bem característicos do século XVII. Outro fenômeno que surge nessa agenda de estudos é a tradução. Você poderia falar, em suma, dessas três categorias: "negociação", "mescla", "tradução", na chave de uma agenda de estudos setecentistas para o século XXI.

Fernando Bouza: As possibilidades de negociação, tradução e mistura são muito grandes, dada a sua natureza transversal. Além da "agenda filipina", agora mesmo na historiografia vivemos um enorme interesse pela transversalidade que, de fato, tem a ver com a recuperação de horizonte. Ela teria a ver com o espaço, mas, também, com o tempo, algo que viria 
reduzir a nossa insistência na memória. A meu ver, as três realidades antes mencionadas são transversais, e especialmente as traduçóes possuem algo de negociação.

Em primeiro lugar, no campo concreto da historiografia filipina, o grande momento da negociação seria, sem dúvida, 1580, um momento histórico com estatuto polêmico, entre a conquista e a negociação. Convém recordar que insistir no perfil negociado de 1580 em Portugal náo supóe, de modo algum, ignorar a existência de conflito. De uma forma um tanto simplista, se pode pretender que a negociação supóe a ausência de conflito. De modo algum. Negociar é uma maneira distinta de apresentar a solução de um conflito. Existe guerra com negociação e, é claro, existe negociação com guerra. No período 1578-1581, talvez o que se encontre seja uma negociação com a ameaça de guerra ou com uma guerra aberta, com episódios muito cruéis como os saques do Porto e de Lisboa. De fato, depois do saque do Porto as autoridades filipinas realizaram uma minuciosa investigação, uma visita, conservada num arquivo privado madrileno, que identifica com detalhes os roubos, destruiçóes e violências das tropas castelhanas. É um documento que não deixa nenhuma dúvida sobre os terríveis acontecimentos. Mais tarde, o aparecimento dos jaezes das cavalarias de D. Sebastiáo, na cidade andaluza de Málaga, demonstra o negócio que alguns quiseram fazer com o que foi roubado de Lisboa. Por sua vez, num espólio particular, D. Antônio I, prior do Crato, levou consigo à França os relicários de corpos santos reunidos pelos Avis no Palácio de Lisboa. (A história de como essas relíquias acabaram na Bélgica, onde hoje se encontram, exigiria uma atenção muito mais particular.) Em Portugal de 1580 há destruição e há guerra, sem dúvida, mas ao mesmo tempo o conflito também se traduz em formas de negociação. Em suma, a monarquia que Felipe II construía era uma monarquia que se fundamentava na resolução de conflitos, fosse pela violência militar, fosse, como em tantas ocasióes, sobre a base de negociaçôes. Durante todo o período filipino, as formas de negociação foram sucessivas. Inclusive no final da década de 1630, com o conde Duque de Olivares, assistimos a formas de negociação, apesar de terem fracassado. Refiro-me à tentativa de Olivares de redefinir um novo Portugal, distinto ao de 1580 , que não se baseava na aliança com elites territoriais, mas num pacto fiscal negociado com as cidades, especialmente do interior, com Portugal do sertão. Olivares colocou o futuro desse novo Portugal em figuras comissariadas, como Francisco Leitão, que, de fato, alcançou avanços parciais que supunham uma ruptura com a ordem anteriormente negociada (e que, em boa medida, deve ser colocada em relação com o advento do Primeiro de Dezembro de 1640).

Em segundo lugar, quanto à "mescla", na monarquia ibérica foram estabelecidas, sem dúvida, fronteiras jurisdicionais que compartimentavam o espaço de uma monarquia compósita, unida mas separada. São as fronteiras internas sobre as quais John H. Elliott e tantos outros - inclusive, eu mesmo - insistiram. Não obstante, existe aí também uma transversalidade, e essas fronteiras internas da monarquia são muito porosas. A escala global da monarquia ibérica é uma realidade na qual as coisas se misturam e se movem sobre as ditas 
fronteiras jurisdicionais. Sobre essas fronteiras se movem as elites, mas também os livros, as imagens, os alimentos, usos e práticas, criando formas mescladas. Creio que a monarquia dos Felipes se transforma numa espécie de laboratório no qual a "mescla" como forma de globalização merece ser estudada.

Há pouco tempo foram restauradas as pinturas originais de uma das três torres do Palacio del Pardo, nas redondezas de Madri, feitas em tempos de Felipe II. Ao restaurar uma sala foi encontrada uma série de afrescos de animais, tanto do Velho como do Novo Mundo. A reconstrução da chegada dessas imagens de animais a Madri, ou dos próprios espécimens, nos permitiria trabalhar com a ideia de "mescla" global. Mas, também, com as histórias de vida que essas imagens nos contam, trajetórias pessoais sobre todo o espaço transversal da monarquia. Há, como bem sabe Stuart B. Schwartz, muitos casos interessantes, como por exemplo o de italianos a serviço da monarquia, sob o mando de castelhanos na Bahia ou em Pernambuco para defender o Brasil contra os holandeses. Ou seja, os italianos não lutaram no território da Itália, os castelhanos no de Castela e os portugueses e brasileiros no Brasil. As tropas estavam misturadas, da mesma forma que os missionários estavam misturados. Ao trabalhar com histórias de vida de missionários, nos deparamos sempre com algum que esteve em Portugal, na Guiné, nas Canárias, na Catalunha ou no Caribe; missionários que estiveram na América e regressaram à Europa e aplicaram sua experiência das Índias na velha Europa.

Pode-se falar também de transversalidade nas práticas, nos interesses econômicos ou na criação de novos mercados. No final do primeiro quarto do século XVII e através de um memorial impresso em Castela, Buenos Aires pede permissão para entrar no comércio com Angola e com o Brasil. Esta é uma realidade que só é possível graças a Portugal dos Felipes e sua pluricontinentalidade.

Por fim, lhes apresento outro caso que considero mais interessante do que o dos italianos na Bahia: é o testemunho da presença de índios da Patagônia no Rio de Janeiro. Casos como este me permitem estabelecer uma visão de América, de uma América ibérica que se reconhece e funciona como um contínuo. Há pouco tempo, pude escrever um artigo com o título "Dois Felipes e um Rio", publicado na Revista de História da Biblioteca Nacional (n. 90, março 2013) sobre a morte de um índio da Terra do Fogo na cidade do Rio de Janeiro, ainda no início do Portugal filipino.

E, por último, a tradução, que, creio, é uma maneira muito interessante de entrar no mundo filipino. Gostaria de imaginar a própria monarquia como uma forma de tradução, como uma forma de negociação entre o oral, o visual e o escrito, entre os ditos popular e letrado, entre jurisdiçóes, entre línguas. Como Edmund Chilmead escreveu em 1660, “we are fallen into an age of translation", uma época em que tudo se misturava e tudo se traduzia.

A meu ver, a agenda filipina tirou a sorte grande. Reconheço, é claro, que não podemos atribuir tudo o que acontece no Brasil, nesse período de 1580 a 1640, aos Felipes, porque 
existem coisas que vêm de trás, e que, possivelmente, se produzem por forças exclusivamente autônomas. Mas este parece ser, sim, um "laboratório", termo que uso com plena consciência. Nesse laboratório seria possível trabalhar com todo tipo de mescla: de espaços, de pessoas, de territórios, de interesses, de práticas, de mundos que se enfrentam a realidades distintas e que encontram formas de negociação ou formas de destruição - porque também essa é uma história de destruição. O período tem, além disso, uma vantagem, que do ponto de vista histórico não devemos esquecer: a sua duração. Ou seja, a família que, no Rio, recebeu o pobre índio da Terra do Fogo, como lhes contava, chegado da Espanha, mas originário da Patagônia, pode ser a mesma família que em 1640 estava envolvida com a Restauraçáo. São 60 anos, um tempo suficientemente longo para um observatório amplo, mas durante o qual é possível que uma mesma pessoa estivesse presente no momento da Sucessão em 1580 e no da Restauração em 1640. E isso dá uma perspectiva de histórias de vida, pelas quais sinto uma predileção bastante especial, como vocês podem imaginar.

Andrea Daher: Esta foi a sua segunda entrevista a Topoi e sua primeira visita ao Brasil, onde falou ao público brasileiro e não deixou de visitar bibliotecas e arquivos. Desejamos que, conhecendo desde já os títulos dos primeiros livros dos acervos das bibliotecas brasileiras, possa renovar continuamente a curiosidade sobre os últimos. 